\title{
New genera of brachyceran flies (Diptera: Xylomyidae and Apsilocephalidae sensu auctorum) from mid-Cretaceous Hukawng Valley Burmese amber
}

\author{
MÓNICA M. SOLÓRZANO KRAEMER ${ }^{a} \&$ JEFFREY M. CUMMING ${ }^{b}$ \\ ${ }^{a}$ Forschungsinstitut und Naturmuseum Senckenberg, Senckenberganlage 25, 60325 Frankfurt am Main, Germany. \\ monica.solorzano-kraemer@senckenberg.de \\ ${ }^{b}$ Invertebrate Biodiversity, Agriculture and Agri-Food Canada, 960 Carling Avenue, Ottawa, Ontario, Canada K1A 0C6. \\ jeff.cumming@canada.ca
}

\begin{abstract}
Two new genera and species from the family Xylomyidae: Pankowskia primera, gen. et sp. nov., Cretarthropeina perdita gen. et sp. nov., and one genus and species incertae sedis, closely related to the family Apsilocephalidae: Kuhwahldyia indefinita gen. et sp. nov. are described from mid-Cretaceous Hukawng Valley Burmese amber. A male Xylomyidae is described for the first time from this amber. The systematic position of each new taxon is discussed.
\end{abstract}

Keywords: new genera, Cretaceous amber, Myanmar, taxonomy, insect

\section{Introduction}

The families Xylomyidae Meijere, 1913 and Apsilocephalidae Nagatomi et al., 1991 are mostly uncommon, either in the recent or fossil record. In amber the family Xylomyidae has been reported in Cretaceous ambers from Myanmar (with three species described), Lebanon and possibly from Spain (Grimaldi, 2016); additionally one compression fossil from the Jurassic of Kazakhstan has been described by Mostovski (1999). In Eocene Baltic amber one species is known, and none are yet known from the Miocene ambers. Today the family is relatively small with 143 recent described species worldwide classified into four genera (Grimaldi, 2016), with the vast majority belonging to the genus Solva Walker, 1859 (Woodley, 2011).

The family Apsilocephalidae appears to be a more common family in Cretaceous ambers. Described specimens are all known from mid-Cretaceous Burmese amber (probably because descriptive works on this amber are being intensively produced at the moment). The fossil genera Kumaromyia Grimaldi \& Hauser, 2011 (in Grimaldi et al., 2011); Burmapsilocephala Gaimari \& Mostovski, 2000; Myanmarpsilocephala Zhang et al.,
2017 and Irwinimyia Zhang et al., 2017 are all described from Burmese amber. In addition, in the recent genus Apsilocephala Kröber, 1914 one fossil species has been described from Eocene Baltic amber, another has been described from Eocene Florissant shale, USA (Hauser, 2007; Zhang et al., 2107), and one fossil has also been placed as near Apsilocephalidae (Grimaldi et al., 2011). Apsilocephalidae is an enigmatic family with three described genera, two of them monotypic and diagnosed by the presence of surstyli on the male genitalia, three sclerotized spermathecae and $\mathrm{R}_{5}$ ending at apex of the wing (Winterton \& Irwin, 2008). However, the status and precise limits of the family remain controversial (e.g. Sinclair et al. 1994; Gaimari \& Mostovski 2000; Hauser \& Irwin 2005).

Grimaldi et al. (2002) indicated that the Burmese amber paleobiota can be attributed to a fully tropical environment. According to Morley (2018), South-East Asia was characterized during the Early Cretaceous by an abundance of gymnosperms of Cheirolepidaceae (extinct gymnosperms) and Araucariaceae, suggesting seasonally dry vegetation. Xylomyidae, commonly known as wood soldier flies, are xylophagous and are associated with dead or dying wood (Stubbs et al., 2001). The biology of Apsilocephalidae is virtually unknown with adults of Apsilocephala having been collected in emergence traps over loose friable soil (Gaimari \& Mostovski, 2000). Three recent genera of Apsilocephalidae are recognized from south-western North America, Tasmania, and New Zealand(Winterton \& Irwin, 2008). Members of the closely related, possible sister group, Therevidae, are common in arid and semiarid regions; however representatives of that family are also present in mountain areas and in the moist tropics (Gaimari \& Webb, 2009).

Herein we describe three new genera and species, Pankowskia primera, gen. et sp. nov. and Cretarthropeina perdita gen. et sp. nov. from the family Xylomyidae, and one incertae sedis, closely related to the family 

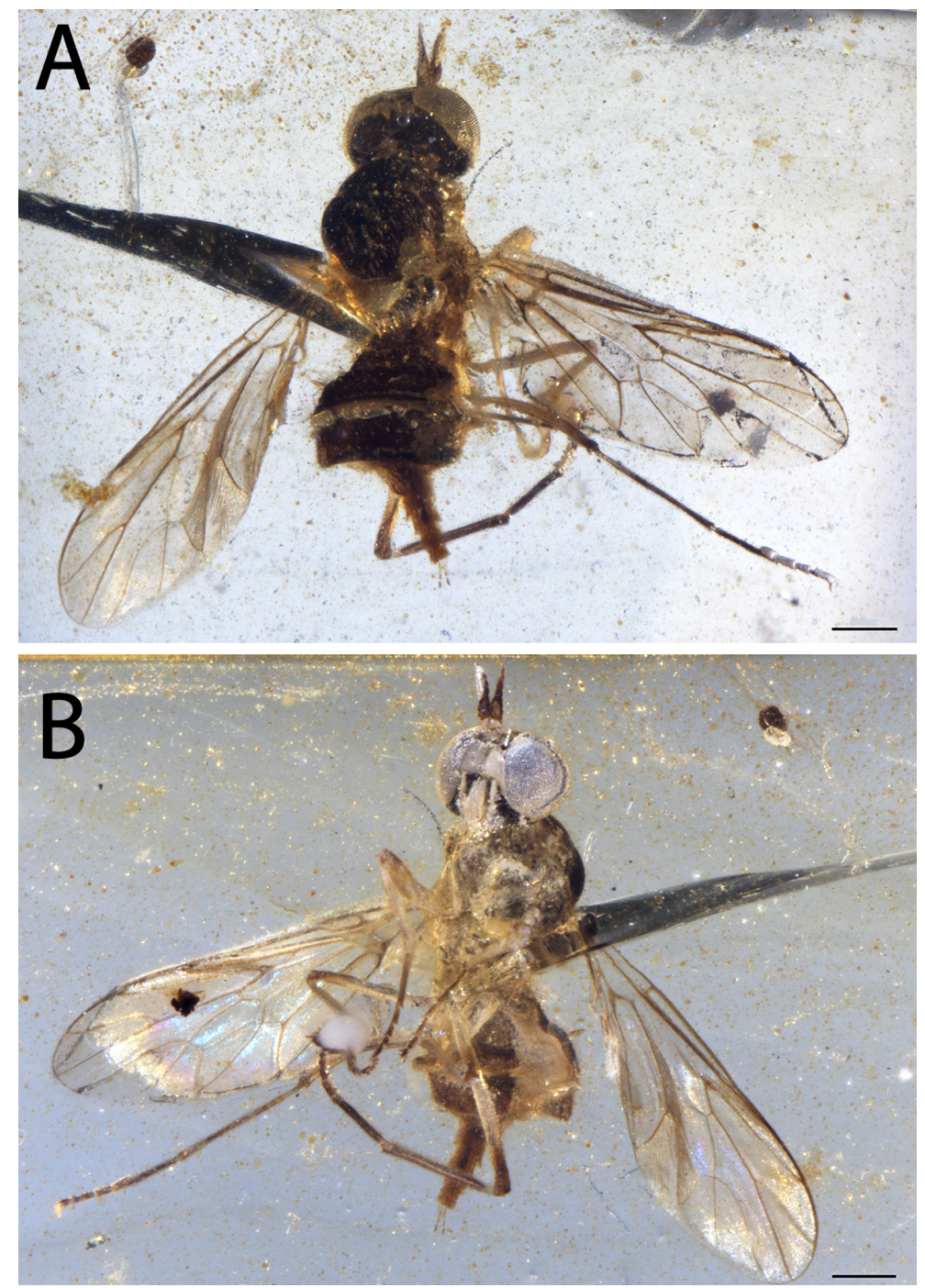

FIGURE 1. Holotype SMF Be 12425a Pankowskia primera gen. et sp. nov., $q$, habitus. A, Dorsal view. B, Ventral view. Scale bars $=0.5 \mathrm{~mm}$.

Apsilocephalidae, Kuhwahldyia indefinita gen. et sp. nov. All pieces of amber are from mid-Cretaceous Hukawng Valley in Myanmar.

\section{Material and methods}

The specimens described herein were were donated by the Pankowski family to the Senckenberg Forschungsinstitut und Naturmuseum, Frankfurt, Germany (SMF), probably collected from the Hukawng Valley of Kachin Province, Myanmar (for locality see Kania et al., 2015: Fig. 1). The age of Burmese amber is radiometrically dated at $98.79 \pm$ $0.62 \mathrm{Ma}$ based on U-Pb zircon dating of the volcanoclastic matrix (Shi et al., 2012). The specimens are preserved in three pieces of yellow amber with some impurities and two pieces have syninclusions. The pieces were cut, polished and embedded in Araldit 2020 to avoid oxidation through time while stored at SMF (catalogue numbers
SMF Be 12425-12427). The specimens were examined under a Nikon SMZ1000 stereomicroscope. Photographs were taken using a Nikon SMZ25 microscope. Drawings were made using a camera lucida attached to the Nikon SMZ1000 stereomicroscope.

Morphological terms follow Cumming \& Wood (2017). Abbreviations of morphological features: aed, aedeagus; $\mathrm{bm}=$ basal medial cell; $\mathrm{br}=$ basal radial cell; cua $=$ anterior cubital cell; $\mathrm{CuA}+\mathrm{CuP}=$ anterior branch of cubital vein + posterior branch of cubital vein; $d=$ discal cell; epiprct, epiproct; goncx, gonocoxite; gonst, gonostylus; $\mathrm{h}=$ humeral crossvein; $\mathrm{M}_{1}-\mathrm{M}_{4}=$ medial veins; $\mathrm{m}-\mathrm{cu}=$ medial-cubital crossvein; $\mathrm{pm}$, paramere; $\mathrm{R}_{1}-\mathrm{R}_{5}=$ radial veins; $\mathrm{Rs}=$ radial sector; $\mathrm{Sc}=$ subcostal vein; $\operatorname{tg}$, tergite.

The nomenclatural acts used herein have been registered in ZooBank. The LSID for this publication is: urn: 1sid:zoobank.org:pub:26DEB498-26D7-4EB787BE-0593EC15164F. 

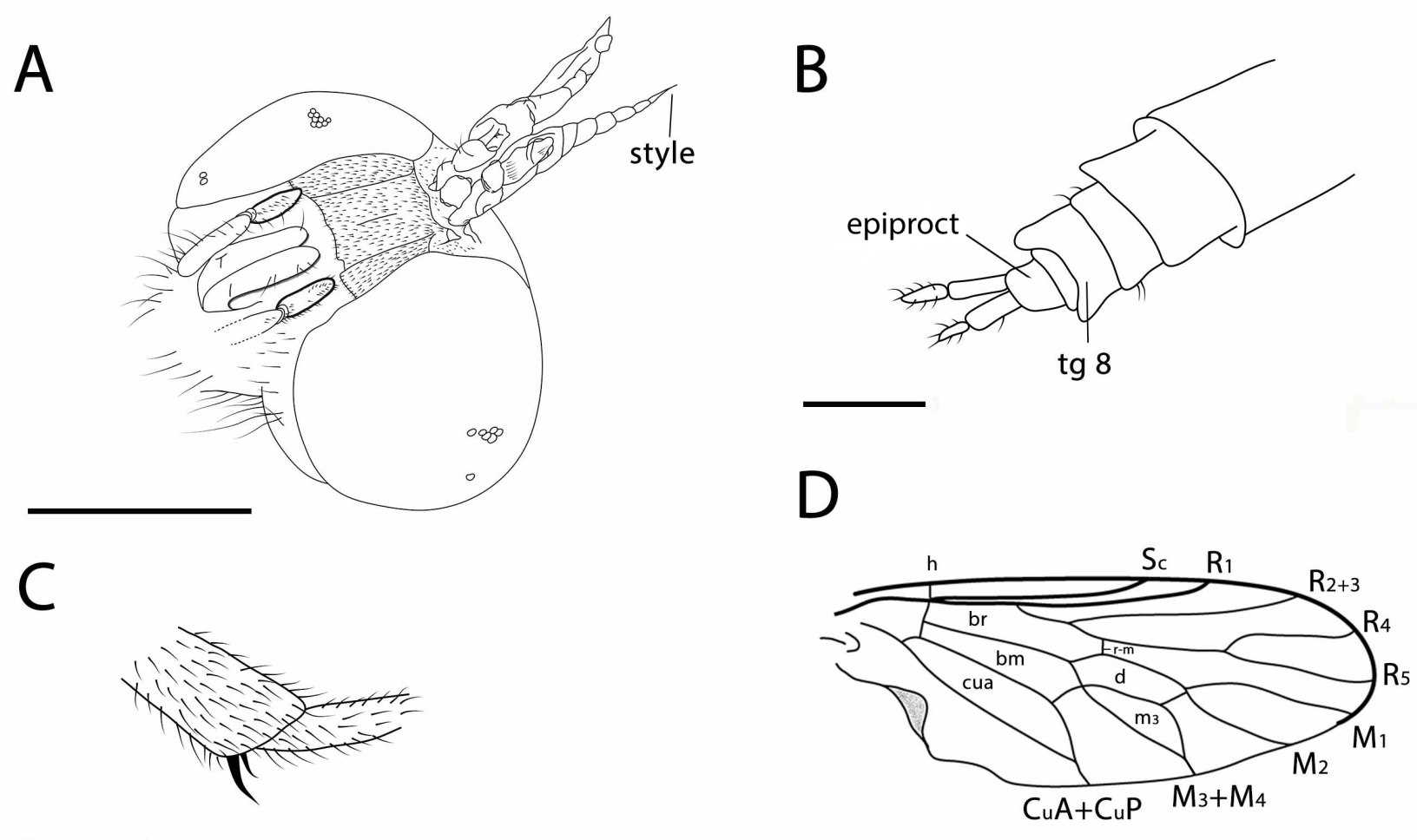

FIGURE 2. Holotype SMF Be 12425a Pankowskia primera, gen. et sp. nov., +. A, Head. B, Terminalia. C, Mid-tibial spur. D, Right wing. Scale bars $=0.5 \mathrm{~mm}$ in A and $\mathrm{D}$, and $0.1 \mathrm{~mm}$ in B and C.
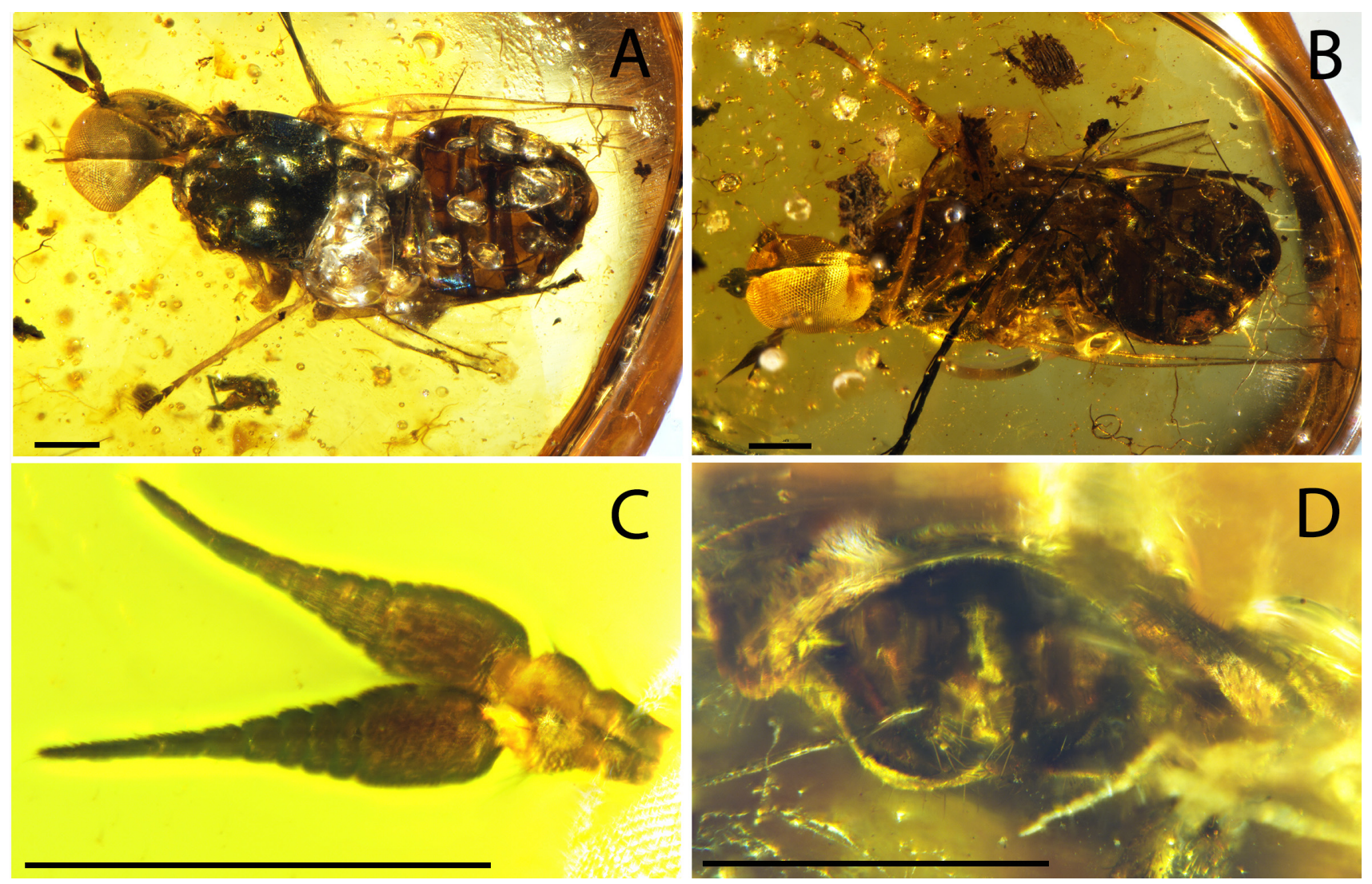

FIGURE 3. Holotype SMF Be 12426a Cretarthropeina perdita, gen. et sp. nov., ô. A, Habitus in dorsal view. B, Habitus in ventral view. C, Antennae. D, Genitalia. Scale bars $=0.5 \mathrm{~mm}$. 


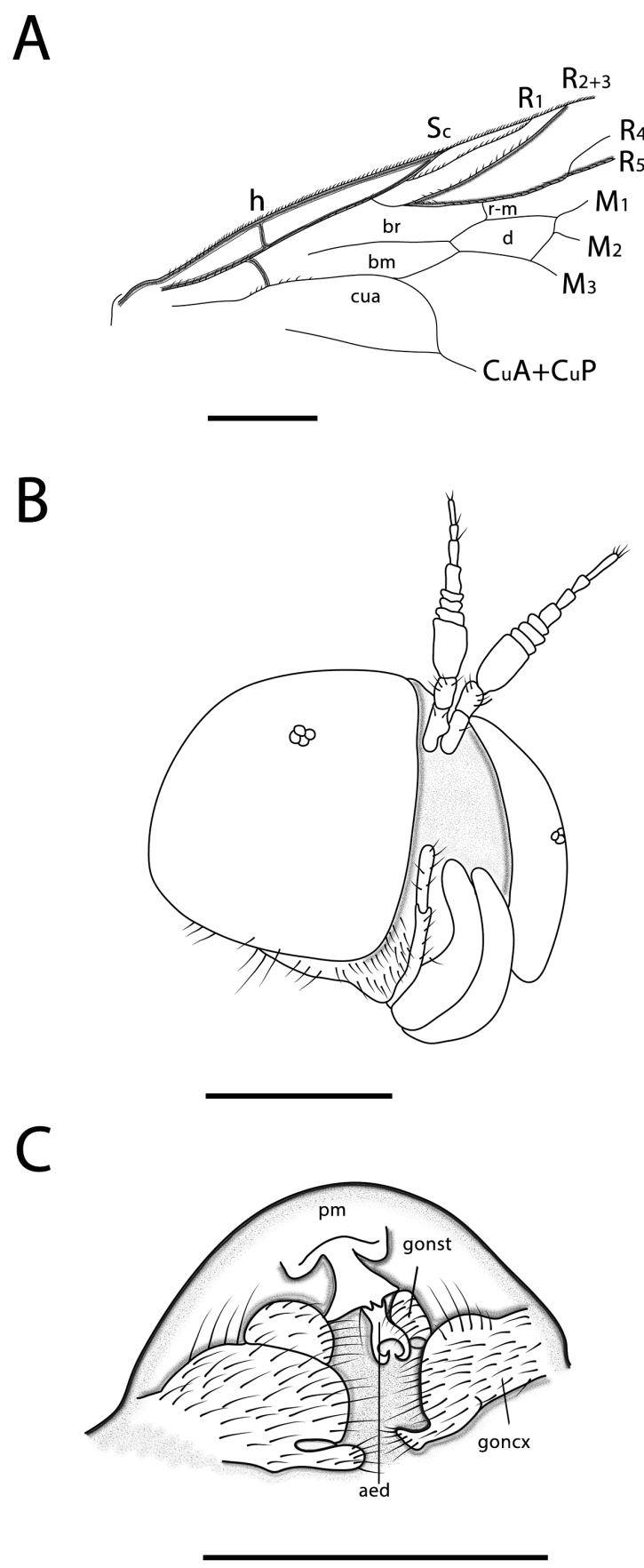

FIGURE 4. Holotype SMF Be 12426a Cretarthropeina perdita gen. et sp. nov., $\hat{\jmath}$. A, Base of right wing. B, Head. C, Genitalia. Scale bars $=0.5 \mathrm{~mm}$.

\section{Systematic Palaeontology}

Order Diptera Linnaeus, 1758

Family Xylomyidae Meijere, 1913

Pankowskia gen. nov.

Type Species. Pankowskia primera, sp. nov., by present designation.

Etymology. The patronym honors the Pankowski family for the donation of several fossil amber species to the Senckenberg Research Institute and Museum, and for allowing for their scientific description. The gender of the name is feminine.

Diagnosis. Obvious tergal sulci and no thickened node or weak area on the short stem of vein Rs. It is distinguished from Cretasolva Grimaldi, 2016 and Archsolva Grimaldi, 2016 by the following: having the apical flagellomere long but the style half as long as the apical flagellomere, and by having transverse sulci on tergites 3-5. As in Cretasolva, Pankowskia has the wing long and slender with vein $\mathrm{C}$ ending at apex of $\mathrm{M}_{1}$; Rs not thickened or weakened; vein Cup very long, with apex meeting $\mathrm{CuA}$ near midlength of wing; cell $\mathrm{m}_{3}$ long and narrow, nearly reaching wing margin $\left(\mathrm{M}_{3}+\mathrm{M}_{4}\right.$ spur short). As in Archsolva, Pankowskia has 0-2-1 short tibial spurs, but these are clearly shorter than the apical width of tibia.

\section{Pankowskia primera sp. nov.}

(Figures 1-2)

urn:lsid:zoobank.org:act:2DF018D7-7E15-449A-AF3216DCF3372716

Diagnosis. As for genus.

Description. Based on a unique female. Slender bodied with slender wings (Fig. 1), legs of moderate length. Body length (excluding antennae, including cerci) $3.7 \mathrm{~m}$; thorax length $1.3 \mathrm{~mm}$; wing length 3.3 $\mathrm{mm}$; abdomen length (including cerci) $1.9 \mathrm{~mm}$. Head: Broader than long (Fig. 2A), slightly broader than thorax, slightly compressed anteroposteriad, broad frontally. Frons relatively broad, width slightly greater than distance between outside margins of lateral ocelli. Face concave (clypeus not observable). Eye: Relatively large, occupying most of head surface in lateral, frontal, and dorsal views. Margins with frons parallel. Eye completely bare, facets not differentiated. Ocelli slightly raised above surface of frons. Antenna: Submoniliform, with eight flagellomeres evenly tapered from broad basal one to narrow apical flagellomere, apical one with style half so long as the last flagellomere (Fig. 2A). Flagellomere lengths in mm: $0.07,0.07,0.03,0.03,0.06,0.06,0.035$, 0.055 , style 0.025 . Scape and pedicel small; antennal sockets very close, situated in ventral half of frons. Mouthparts: Palps directed forward; 2-segmented, basal segment slightly slender; apical one oval. Proboscis short, only labellum exposed; labellum large, fleshy, laterally flattened. Thorax: Dorsum of scutum, scutellum, and portion of anepisternum with dense, very fine, setigerous punctation, denser on scutellum; no macrosetae or long pilosity. Transverse suture short, mostly lateral (pleural), with distinct impression dorsolaterally. Scutellum slightly wider than long, without spines; narrow, short but distinct 

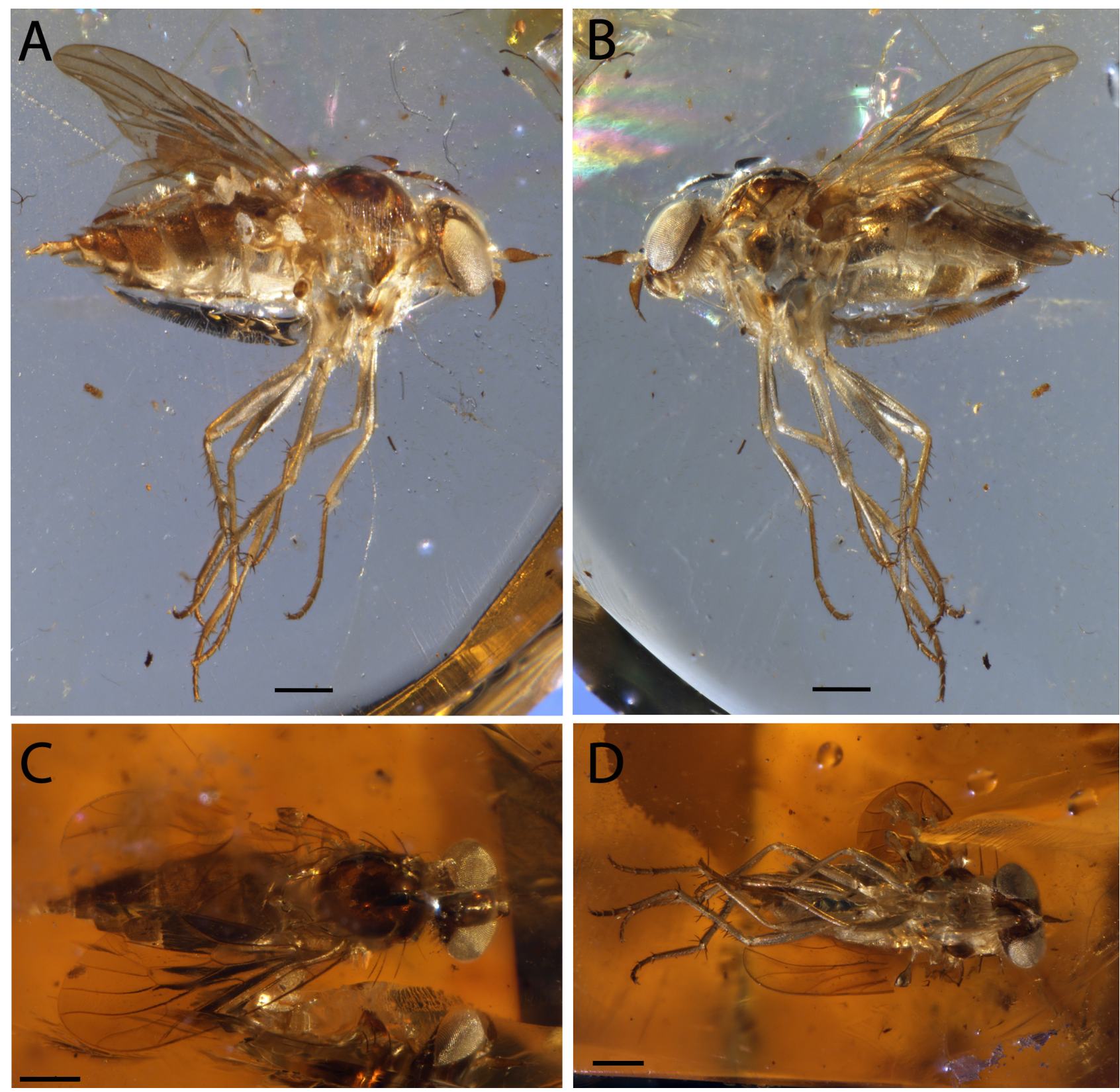

FIGURE 5. Holotype SMF Be 12427a Kuhwahldyia indefinita, gen. et sp. nov., $q$, habitus. A, Right lateral view. B, Left lateral view. C, Dorsal view. D, Ventral view. Scale bars $=0.5 \mathrm{~mm}$.

prescutellum present. Pleural sutures not easily observed because of some bubbles and a crack going through the pleural part of the inclusion; pleura large oblique. Wing: Long, slender, Width $1.1 \mathrm{~mm}$. Length $3.3 \mathrm{~mm}$, veins well developed, most are well sclerotized, lightest at base of $\mathrm{R}$ and M. No minute setulae on veins. Vein $\mathrm{C}$ ends just past tip of $\mathrm{M}_{1}$ (Fig. 2D). No pterostigma. Sc complete, ca. $0.48 \times$ wing length; $R_{1} 0.62 \times$ wing length, close and parallel to Sc; Rs short, $\mathrm{R}_{2+3}$ closer in the middle to $\mathrm{R}_{1}$; Rs without thickened node or weak area; fork of $R_{4}+R_{5}$ asymmetrical, $\mathrm{R}_{4} 0.78 \times$ length of $\mathrm{R}_{5}$. Crossvein $\mathrm{r}-\mathrm{m}$ close to base of cell $\mathrm{d}$, $\mathrm{M}$ veins connected to apex of cell d; $\mathrm{M}_{1}, \mathrm{M}_{2}$ parallel; cell $\mathrm{m}$ long, slender, $\mathrm{M}_{3}+\mathrm{M}_{4}$ forming a short stem; crossvein m-m present at apex of cell d.
Cell $\mathrm{d}$ long and narrow, cells br and bm of equal length. Vein $\mathrm{CuP}$ long and meeting $\mathrm{CuA}$, cell cua closed. Vein $\mathrm{CuA}+\mathrm{CuP}$ short; anal lobe and alula present but small. Legs: Length moderate. Pattern of color of hind legs with the base of femur, tibia and tarsomeres obscured. Coxae robust, meso- and metacoxae meeting, distant from procoxa. Relative lengths of leg segments: femur $>$ tibia $>$ basitarsus $>$ combined lengths tarsomeres $2-5$. Tibial spurs $0-2-1$; spurs very thin, lengths shorter than apical width of tibiae (Fig. 2C). No spinules on ventral surface of hind femur. Acropod with well-developed simple claws; pulvilli small, ca $0.5 \times$ length of claw; empodium setiform. Abdomen: Longer than thorax, broad to tergite 3, and clearly thinner and tapered down from tergite 4 to tergite 


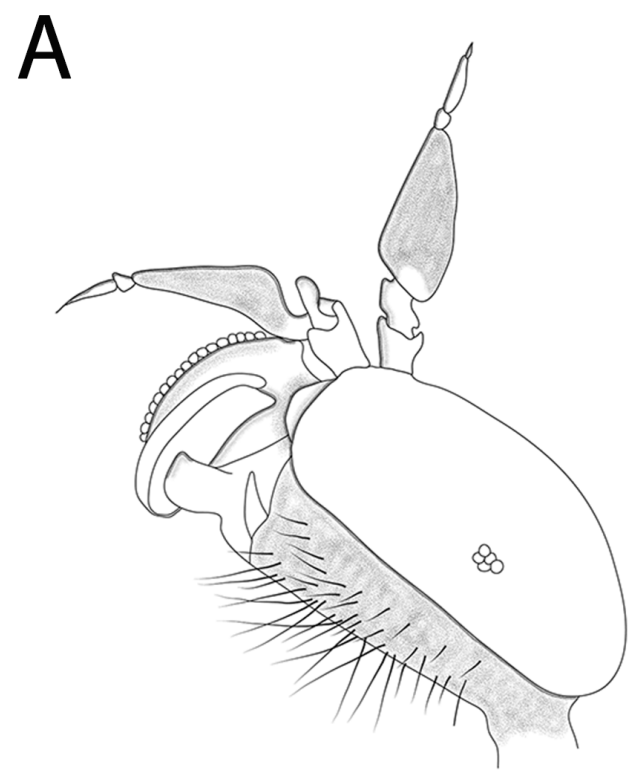

B

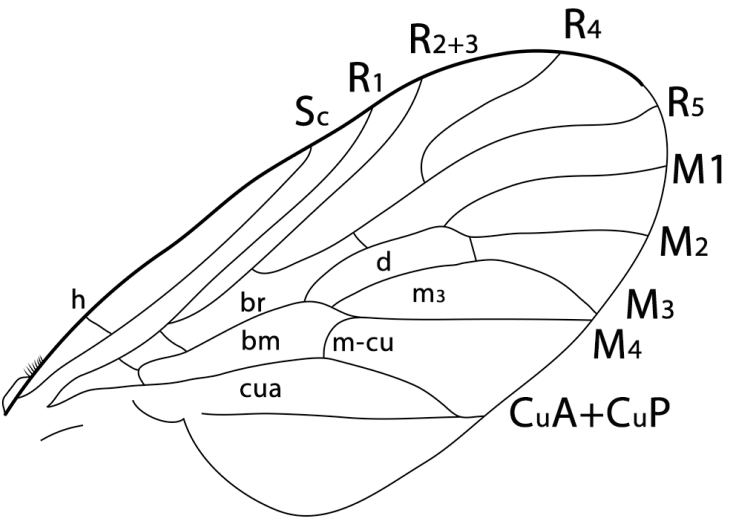

FIGURE 6. Holotype SMF Be 12427a Kuhwahldyia indefinita, Solórzano gen. et sp. nov., +. A, Head. B, Right wing. Scale bars $=0.5 \mathrm{~mm}$.

10; dorsoventrally flattened; tergite 2 to 3 and 3 to 4 with transverse sulci. Cercus 2 segmented, basal cercomere slightly longer than apical one (Fig. 2B). Sternites well developed but not meeting tergites laterally, abdominal pleural membrane well exposed.

Type. Holotype female, SMF Be 12425a: Myanmar: Kachin State, near Myitkyina (mid-Cretaceous: Earliest - Cenomanian (Shi et al. 2012)). Specimen is complete. The piece of amber also contains plant remains.

Etymology. Referring to the first specimen found in this new genus

\section{Cretarthropeina gen. nov.}

Type Species. Cretarthropeina perdita, sp. nov., by present designation.

Etymology. Derived from Arthropeina Lindner, 1949 and Cretaceous, because of the similarities with the genus Arthropeina. The gender of the name is feminine.

Diagnosis. Obvious tergal sulci. It is distinguished from Cretasolva, Archsolva and Pankowskia by the following: having the apical flagellomere long and without style; vein $\mathrm{CuP}$ extremely long, with apex meeting $\mathrm{CuA}$ at midlength of wing; $\mathrm{M}_{4}$ missing. Cretarthropeina has 0-2-0 short tibial spurs, compared to Archsolva and Pankowskia with 0-2-1, and Cretasolva with 0-2-2.

Cretarthropeina perdita sp. nov.

(Figures 3-4)
urn:1sid:zoobank.org:act:1F95BC49-04F4-4431-928E442088A6BA2B

Diagnosis. As for genus.

Description. Based on a unique male (Figs. 3A, 3B). Slender bodied with slender wings, legs of moderate length. Body length (excluding antennae) about $4.4 \mathrm{~mm}$; thorax length $1.63 \mathrm{~mm}$; both wings broken. Head: Broader than long, slightly broader than thorax, compressed anteroposteriad, broad frontally. Frons relatively broad, width slightly greater than distance between outside margins of lateral ocelli. Face concave (clypeus not observable). Eye: Relatively large, occupying most of head surface in lateral and frontal, and occupying the whole head surface in dorsal views. Margins with frons parallel. Eye completely bare, facets not differentiated. Ocelli slightly raised above surface of frons. Antenna: Submoniliform, with 8 flagellomeres evenly tapered from broad basal, three broad and narrow, three narrow, and one apical long with a short style (Figs. 3C and 4B). Flagellomere lengths in mm: 0.16, 0.03, 0.03, 0.03, 0.04, 0.05, 0.05, 0.13. Scape and pedicel small; antennal sockets very close, situated in ventral half of frons. Mouthparts: Palps directed forward; 2-segmented, basal and apical segments slender and long. Proboscis short, only labellum exposed; labellum large, fleshy, laterally flattened. Thorax: Dorsum of scutum, scutellum, portion of anepisternum with dense, very fine, setae; no macrosetae or long pilosity. Transverse suture short, mostly lateral (pleural), with distinct impression 
dorsolaterally. Scutellum wider than long, without spines; narrow, short but distinct prescutellum present. Pleural sutures not easily observed because of some bubbles and being obscured by legs; pleura large, oblique. Wing: Broken, slender, not all veins well developed, some of them well sclerotized, base of M not developed. Minute setulae on $\mathrm{R}$ veins. No pterostigma in the preserved part of wings. $\mathrm{R}_{1}$ close and parallel to $\mathrm{Sc}$; Rs short without thickened node, $\mathrm{R}_{2+3}$ close to $\mathrm{R}_{1}$. Crossvein $\mathrm{r}-\mathrm{m}$ near $1 / 3$ of base of cell $d$. $M$ veins connected to apex of cell d. $\mathrm{M}_{4}$ absent; crossvein $\mathrm{m}$-cu long. Cell $\mathrm{d}$ long and narrow, cells br and bm almost equal length, vein $\mathrm{M}$ not sclerotized. Vein $\mathrm{CuP}$ long and meeting $\mathrm{CuA}$, cell cua closed. Vein $\mathrm{CuA}+\mathrm{CuP}$ short and curved; anal lobe and alula not visible (Fig. 4A). Legs: Length moderate. Fore and mid coxae robust, metacoxa shorter and distant from mid coxa. Relative lengths of leg segments: femur $=$ tibia $>$ basitarsus $>$ combined lengths tarsomeres $2-5$. Tibial spurs $0-2-0$; spurs very thin, lengths shorter than apical width of tibiae. No spinules on ventral surface of hind femur. Acropod with well-developed simple claws; pulvilli small, ca $0.5 \times$ length of claw; empodium setiform. Abdomen: Only slightly longer than thorax, broad to tergite 7 , dorsoventrally flattened, tergites 2 to 5 with transverse sulci. Male genitalia: Gonocoxite rounded laterally, distal margin strongly projected (Figs 3D and 4C); gonocoxal apodeme absent. Gonostylus with long setae (Fig 4C). Aedeagus elongate, enclosed by the parameres (Fig 4C); acuminate projections lateral to phallus. Epandrium quadrangular, wide, without lateral projections (surstyli).

Type. Holotype male, SMF Be 12426a: Myanmar: Kachin State, near Myitkyina (mid-Cretaceous: Earliest - Cenomanian (Shi et al. 2012)). Specimen is incomplete. The piece of amber contains the following syninclusions: a probable Psocoptera, star hairs, fungal hyphae and detritus.

Etymology. The presence of male specimens of Xylomyidae is very rare in fossil resins. Perdita refers to loss of the specimen from its normal environment.

Discussion. The preceding new genera are included in the family Xylomyidae because of the presence of spurs on the mid and hind tibiae, the conical antennae, elongated discal cell, and cell $\mathrm{m}_{3}$ closed before the wing margin. Within the family Xylomyidae, four extant genera are recognized: Arthropeina Lindner, 1949, Solva, Xylomya Rondani, 1861, and Coenomyiodes Brunetti, 1920 (Fachin \& Amorim, 2014); however Coenomyiodes may be a synonym for Solva (Nagatomi, 1993). These genera can be separated from the fossils described here by the following characters: Arthropeina has the antennal flagellum with two discrete apical flagellomeres, with the last flagellomere slender, at least twice as long as the penultimate flagellomere. Solva has the hind femur armed with ventral tubercles. Xylomya has the last two flagellomeres not discretely differentiated from the more basal ones with the last flagellomere not slender.

\section{Family Incertae sedis, near Apsilocephalidae Nagatomi et al., 1991}

\section{Kuhwahldyia gen. nov.}

Type species. Kuhwahldyia indefinita sp. nov., by present designation.

Etymology. Patronym dedicated to the place where the specimen was described. The Kuhwaldstrasse 55 address was where the paleontology department of the Senckenberg Research Institute was housed from 1984 to 2018.

Diagnosis. $R_{4}$ and $R_{5}$ ending at wing apex. Body not stout, with the abdomen longer than thorax; eyes bare; antenna with three flagellomeres, second article smaller than and third, style minute; palp one-segmented; legs and thorax with bristle-like setae, pilosity on the coxae; thickness of metatarsi equal to that of metatibial base; wing with $\mathrm{C}$ ending between apices of $\mathrm{R}_{4}$ and $\mathrm{R}_{5}$; apex of $\mathrm{R}_{5}$ ending near wing tip; $\mathrm{R}_{4}$ and $\mathrm{R}_{5}$ divergent, not parallel for any part of their lengths; base of $\mathrm{R}_{4}$ not perpendicular to stem of $\mathrm{R}_{4+5}$ and $\mathrm{R}_{5} ; \mathrm{m}_{3}$ open.

Remarks. Kumaromyia burmitica Grimaldi \& Hauser, 2011 (in Grimaldi et al. 2011) is a similar species preserved in Burmese amber, but Kuhwahldyia indefinita has a larger body size (wing width $1.1 \mathrm{~mm}$, vs. $0.75 \mathrm{~mm}$ in the holotype of $K$. burmitica), and differs venationally, specifically by cell $\mathrm{m} 3$ being open (vs. closed in $K$. burmitica), and having nine macrosetae on the thorax and notopleuron (vs. 8 in K. burmitica).

\section{Kuhwahldyia indefinita sp. nov.}

(Figures 5-6)

urn:1sid:zoobank.org:act:BE2B589E-79CF-4FB4-BE1953F263866601

\section{Diagnosis. As for genus.}

Description. Total body length ca. $3.8 \mathrm{~mm}$, wing length $2.60 \mathrm{~mm}$ (Fig. 5), with some pilosity on the coxae and on the last abdominal tergites. Head: $1.1 \mathrm{~mm}$ wide with large eyes. Eyes bare, hemispherical in lateral view (posterior margin flat), no dorsoventral differentiation of facets; inner margins of eyes parallel, distance between eyes $0.3 \mathrm{~mm}$. Frons slightly convex, not protruding anteriad; with numerous fine setulae, with calli. Face ("subcranial cavity") depressed, dark and glabrous. Maxilla with bases (cardo) sclerotized and partially fused, palpus one-segmented and shorter than labellum. Postgena well developed, with numerous fine setae (pilosity). Antenna: Antennal scape and pedicel small, approximately equal 


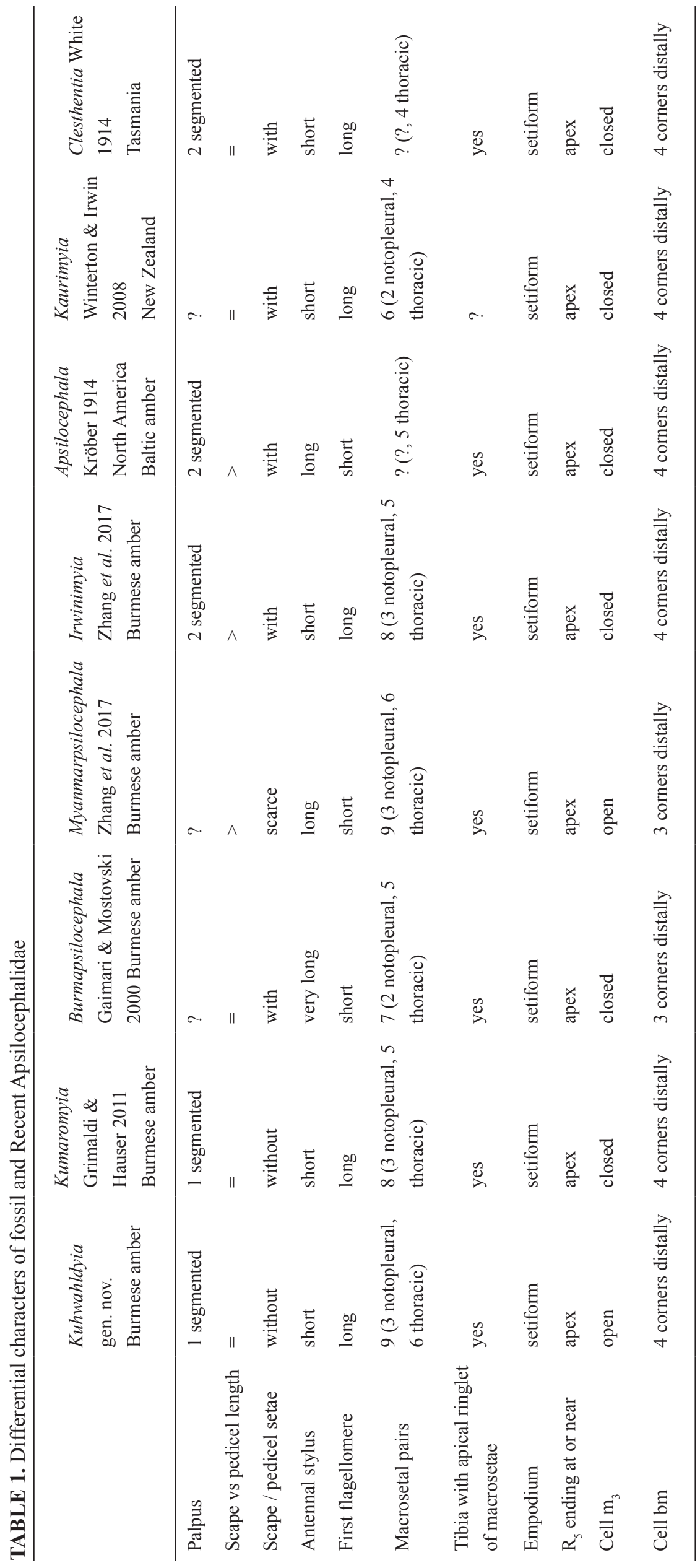


in size, devoid of thick setae; basal flagellomere largest antennomere, drop-shaped, with dense setulae (no setae); apical two antennomeres (including apical style) small, fine, with style longer than penultimate antennal article (Fig. 6A). Thorax: Pleura apparently devoid of fine or bristle-like setae; scutum with at least nine pairs of setae. Scutum with three pairs of notopleurals and six pairs in supraalar region and some setulae; no cervical/ postcervical setae. Legs: With thick, stiff setae, primarily on tibiae and tarsomeres; fore tibia slender, hind tibia thickest. Fore leg: femur with lateral row of ca. four long fine setae, tibia with one anterior and seven pre-apical setae. Mid leg: femur lateral row of ca. four long fine setae, tibia with dorsal row of six setae on dorsal surface and seven apically. Hind leg: coxa with small knob on ventral surface; femur devoid of setae, tibia with dorsal row of 15 setae and seven apically. Basitarsus on fore and mid leg equal in length, hind basitarsus somewhat shorter and wider. Fore tarsus with ca. five short, stiff setae, mid tarsus with 12 and hind tarsus with about 17 setae. Acropod with pair of large pulvilli, empodium setiform. Wing: Large, $2.6 \mathrm{~mm}$ in length, nearly equal to that of body. Crossvein h long (space between Sc and C deep); Sc long, reaching $1 / 2$ that of wing and slightly shorter than length of $R_{1}$; dorsal surface of $R_{1}$ vein not setose; apex of Sc apparently meeting $\mathrm{C}$. Sc and $\mathrm{R}_{1}$ without pterostigma surrounding apices. Fork of $\mathrm{R}$ and Rs deep, proximal to level of crossvein $h . \mathrm{R}_{2+3}$ with apical curve. Fork of $\mathrm{R}_{4+5}$ somewhat divergent; $\mathrm{R}_{5}$ with apical curve, apex of $\mathrm{R}_{5}$ ending very near apex of wing, slightly posterior to it; $\mathrm{R}_{4}$ slightly curved, distinctly shorter than $\mathrm{R}_{5}$. Cell d slender, greatest width $<0.25 \times$ length. Veins $M_{1}$ and $M_{2}$ almost parallel, $M_{2}$ and $M_{3}$ very divergent, all $M$ veins, except $M_{4}$, attached to apex of cell $\mathrm{d}$. Apex of $\mathrm{M}_{3}$ not meeting apex of $\mathrm{M}_{4}$, cell m3 open (Fig. 6B). Abdomen: $2.0 \mathrm{~mm}$ long (excluding terminalia), $2 \times$ longer than thorax. Tergites 1 , 6 and 7 covered with long fine hairs.

Type. Holotype, female, SMF Be 12427a: Myanmar: Kachin State, near Myitkyina (mid-Cretaceous: Earliest - Cenomanian (Shi et al. 2012). Specimen is complete. The piece of amber does not contain syninclusions.

Etymology. In reference to the difficulties in finding familiar relationships within Apsilocephalidae and the therevid-family group.

Discussion. Kuhwahldyia is placed as incertae sedis and is probably closely related to the family Apsilocephalidae, primarily because of the venation. Thus, the fossil genus belongs to the therevid-family group together with the similar fossil genus Kumaromyia. The present genus is somewhat smaller than most extant described therevid-family group species, but larger than Kumaromyia. According to Grimaldi et al. (2011), therevid-family group features include similar antennal structure, bristle-like setae on the scutum and the legs, a small knob on the hind coxa, as well as venational similarities. Unlike most Therevidae, Kumaromyia and Kuhwahldyia lack any pruinosity and pilosity (except for the postgena), although as already mentioned by Grimaldi et al. (2011), Xestomyzinae and Agaphotinae within the Therevidae are also robust and have sparse pilosity. Both of these fossil genera have $\mathrm{R}_{4}$ and $\mathrm{R}_{5}$ close to the wing apex like all other fossil and extant species of Apsilocephalidae, a putative unique apomorphy (Nagatomi et al., 1991) and unlike Therevidae where each of those two veins is located above and below the wing tip, respectively. Kuhwahldyia also has the frons and face much longer than wide and the face deeply concave, characteristic of some Apsilocephalidae, although this character apparently is not present in all species. However, unlike other Apsilocephalidae and Therevidae, Kumaromyia and Kuhwahldyia lack any thick setae that typically encircle the scape and/or pedicel subapically in both families. In addition, Kumaromyia and Kuhwahldyia have a onesegmented palpus, versus a two-segmented palpus found in other Apsilocephalidae where the palpus structure is known (not known for fossil Burmapsilocephala and Myanmarpsilocephala and Recent Kaurimyia) (Table 1). As pointed out by Grimaldi et al. (2011) for Kumaromyia and also found here for Kuhwahldyia, the short antennal stylus and stout body of these fossil genera is very similar to the extant genus Clesthentia White, 1915. They also suggested that Kumaromyia and now Kuhwahldyia, might belong to a stem-group taxon within the therevid-family group rather than within either the Apsilocephalidae or Therevidae. It is also possible that the Apsilocephalidae as currently defined with the inclusion of five Burmese amber genera and three Recent genera, is likely paraphyletic in relation to some other families in the therevid-family group (i.e., Evocoidae, Therevidae, Scenopinidae). More fossil specimens, particularly males, are still necessary to evaluate these hypotheses.

\section{Conclusion}

The new described genera and species highlight the great amount and diversity of insects found in Burmese amber. The description of these new taxa is relevant for subsequent analysis of Cretaceous arthropod diversity. Why xylomyids are more common in Cretaceous than in Miocene amber is not possible to explain without further taphonomic study of arthropods in gymnosperm tree-resin. Xylophagous Diptera like Sciaridae or Cecidomyiidae and other xylophagous insects living in association with resiniferous trees are very abundant in Miocene and in recent resins (Solórzano Kraemer et al., 2018). Cretaceous ambers also contain abundant xylophagous insects such as 
Coleoptera (Peris, 2016). The presence and abundance of the xylophagous Diptera family Xylomyidae in Burmese amber is therefore not surprising. However, any habitat associations for Burmese amber Apsilocephalidae and allies will basically remain unknown until more life history information becomes available for extant members of this group.

\section{Acknowledgments}

We thank Mark Pankowski and family (Rockville, Maryland, USA) for the donation of the amber pieces. Thanks also to Claudia Franz (SMF) for the management of the amber collection and Robin Kunz for photography and digitization of the drawings (SMF). The manuscript was also improved by the comments of two reviewers, Antonio Arillo (Madrid, Spain) and Dany Azar (Beirut, Lebanon). Financial support was provided by the VolkswagenStiftung project 90946 and the Spanish Ministry of Economy and Competitiveness (project “CRE”, Spanish AEI/FEDER, UE CGL2017-84419).

\section{References}

Cumming, J.M. \& Wood, D.M. (2017) Adult morphology and terminology. In: Kirk-Spriggs, A.H. \& Sinclair, B.J. (Eds.), Manual of Afrotropical Diptera. Volume 1. Introductory chapters and keys to Diptera families. Suricata 4, South African National Biodiversity Institute, Pretoria, pp. 89-133.

Fachin, D.A. \& Amorim, D.D.S. (2014) Taxonomic revision of the Neotropical genus Arthropeina Lindner, 1949 (Diptera: Xylomyidae). Zootaxa, 3827 (2), 231-257.

https://doi.org/10.11646/zootaxa.3827.2.6

Gaimari, S.D. \& Mostovski, M.G. (2000) Burmapsilocephala cockerelli, a new genus and species of Asiloidea (Diptera) from Burmese amber. Bulletin of the Natural History Museum of London (Geology), 56, 43-45.

Gaimari, S.D. \& Webb, D.W. (2009) Therevidae (stiletto flies). In: Brown, B.V., Borkent, A., Cumming, J.M., Wood, D.M., Woodley, N.E. \& Zumbado, M. (Eds.), Manual of Central American Diptera. Volume 1. National Research Council Research Press, Ottawa, Canada, pp. 643-647.

Grimaldi, D.A. (2016) Diverse Orthorrhaphan flies (Insecta: Diptera: Brachycera) in amber from the Cretaceous of Myanmar: Brachycera in Cretaceous amber, Part VII. Bulletin of the American Museum of Natural History, 408, 1-131. https://doi.org/10.1206/0003-0090-408.1.1

Grimaldi, D.A, Arillo, A., Cumming J.M. \& Hauser, M. (2011) Brachyceran Diptera (Insecta). Cretaceous ambers, Part IV, Significant new orthorrhaphous taxa. ZooKeys, 148, 293 332. https://doi.org/10.3897/zookeys.148.1809

Grimaldi,D.A., Engel,M.S.\&Nascimbene, P.C.(2002)Fossiliferous Cretaceous Amber from Myanmar (Burma): Its Rediscovery, Biotic Diversity, and Paleontological Significance. American Museum Novitates, 3361, 1-71.

https://doi.org/10.1206/0003-0082(2002)361<0001: FCAFMB $>2.0 . \mathrm{CO} ; 2$

Hauser, M. (2007) Baltic amber Therevidae and Apsilocephalidae (Diptera). Studia Dipterologica, 14 (1), 37-59.

Hauser, M. \& Irwin, M.E. (2005) Fossil Therevidae (Insecta: Diptera) from Florissant, Colorado (Upper Eocene). Journal of Systematic Palaeontology, 3, 393-401. https://doi.org/10.1017/S1477201905001690

Kania, I., Wang, B. \& Szwedo, J. (2015) Dicranoptycha Osten Sacken, 1860 (Diptera, Limoniidae) from the earliest Cenomanian Burmese amber. Cretaceous Research, 52 (Part B), 522-530.

https://doi.org/10.1016/j.cretres.2014.03.002

Lindner, E. (1949) Neotropische Stratiomyiiden des Britischen Museums in London. The Annals and Magazine of Natural History, 1 (12), 782-821. https://doi.org/10.1080/00222934808653947

Linnaeus, C. (1758) Systema naturae per regna tria naturae, secundum classes, ordines, genera, species, cum characteribus, differentiis, synonymis, locis. Tomus I. Editio decima, reformata Holmiæ: Salvius. https://doi.org/10.5962/bhl.title.542

Meijere, J.C.H. de (1913) Praeda itineris a L.F. de Beaufort in Archipelago indico facti annis 1909-1910. Dipteren I. Bijdragen tot de Dierkunde, 19, 45-69.

Morley, R.J. (2018) Assembly and division of the South and SouthEast Asian flora in relation to tectonics and climate change. Journal of Tropical Ecology, 34 (4), 209-234. https://doi.org/10.1017/S0266467418000202

Mostovski, M.B. (1999) On an interesting find of a brachycerous fly (Diptera, Brachycera) in the Jurassic of Kazakhstan. Paleontological Journal, 33, 406-408.

Nagatomi, A. (1993) Taxonomic notes on Xylomyidae (Diptera). South Pacific Study, 14 (1), 85-93.

Nagatomi, A., Saigusa, T., Nagatomi, H. \& Lyneborg, L. (1991) Apsilocephalidae, a new family of the orthorrhaphous Brachycera (Insecta, Diptera). Zoological Science, 8 (3), 579-591.

Peris, D., Ruzzier, E., Perrichot, V. \& Delclos, X. (2016) Evolutionary and paleobiological implications of Coleoptera (Insecta) from Tethyan-influenced Cretaceous ambers. Geoscience Frontiers, 7 (4), 695-706. https://doi.org/10.1016/j.gsf.2015.12.007

Shi, G.S., Grimaldi, D.A., Harlow, G.E. Wang, J., Wang, J., Yang, M.C., Lei, W.Y., Li, Q.L. \& Li., X.H. (2012) Age constraint on Burmese amber based on $\mathrm{U}-\mathrm{Pb}$ dating of zircons. Cretaceous Research, 37, 155-163.

https://doi.org/10.1016/j.cretres.2012.03.014 
Sinclair, B.J., Cumming, J.M. \& Wood, D.M. (1994) Homology and phylogenetic implications of male genitalia in Diptera - Lower Brachycera. Entomologica Scandinavica, 24, 407432.

https://doi.org/10.1163/187631293X00190

Solórzano Kraemer, M.M., Delclòs, X., Clapham, M., Arillo, A., Peris, D., Jäger, P., Stebner, F. \& Peñalver, E. (2018) Arthropods in modern resins reveal if amber accurately recorded forest arthropod communities. Proceedings of the National Academy of Sciences. https://doi.org/10.1073/pnas.1802138115

Stubbs, A.E. \& Drake, M.C. (2001) British soldierflies and their allies: A field guide to the larger British Brachycera. British Entomological and Natural History Society, London, 528 pp.

Walker, F. (1859) Catalogue of the dipterous insects collected at
Makessar in Celebes, by Mr. A.R. Wallace, with descriptions of new species. Journal of the proceedings of the Linnean Society. Zoology, 4, 90-96.

https://doi.org/10.1111/j.1096-3642.1859.tb00089.x

Winterton, S. \& Irwin, M.E. (2008) Kaurimyia gen. nov.: discovery of Apsilocephalidae (Diptera: therevoid clade) in New Zealand. Zootaxa, 1779, 38-44.

https://doi.org/10.11646/zootaxa.1779.1.3

Woodley, N.E. (2011) A catalog of the world Xylomyidae (Insecta: Diptera). Myia, 12, 417-453.

Zhang, Q.Q., Li, X.K., Xu, B.Q., Zhu, Y.M., Lu, R.Q., Wang, B. \& Yeates D.K. (2017) Two new genera of Apsilocephalidae from mid-Cretaceous Burmese amber, Cretaceous Research, 84, 525-532.

https://doi.org/10.1016/j.cretres.2017.11.026 